\title{
WETLAND ARCHAEOLOGY AND THE STUDY OF LATE MĀORI SETTLEMENT PATTERNS AND SOCIAL ORGANISATION IN NORTHERN NEW ZEALAND
}

\author{
GEOFFREY IRWIN \\ University of Auckland
}

\begin{abstract}
There was probably a period in New Zealand prehistory when the population grew relatively rapidly.... Most of this growth seems to have taken place in northern parts of the North Island. Such an increase would necessitate some readjustments in social organisation, if not in population distribution. Larger social groups in closer proximity may have provided the trigger for $p \bar{a}$ building, and stimulated the quest for both personal status and group prestige.
\end{abstract}

(Davidson 1984: 222)

The study of settlement patterns is of long-standing interest in New Zealand archaeology. This paper focuses on the significant change represented by the appearance and spread of $p \bar{a}$ in late prehistory. Elsdon Best's landmark book, The Pa Maori published in 1927, has greatly influenced subsequent research on $p \bar{a}$ and current researchers are still working through the issues he raised.

Settlement pattern is an established method for studying social organisation, and relationships between sites are used as a proxy for relationships among social groups. Pacific archaeologists routinely consider social trajectories in the past and this requires the use of wider anthropological models.

The paper comprises several parts, but there is a thread of argument between them and they follow what has been an essentially personal approach.

- First, there is a discussion of the problems and prospects of $p \bar{a}$ archaeology. These sites are complex, diverse and remain intractable; nonetheless, an excavation strategy that focuses on the significance of defences is outlined.

- Three wetland sites are taken as examples of settlement at a communal level because of the excellent survival of evidence. The lake village of Kohika provides a snapshot of a Māori community, shortly before the advent of Europeans. Two other examples are a small inland site at Lake Mangakaware and the large site of Oruarangi, which was still occupied at the time of European contact. To consider what changed during New Zealand prehistory, a brief comparison is made between Kohika and Wairau Bar, which was a foundation settlement of primary importance, and in some general respects the evidence has remained much the same. 
- Carrying insights from wetland archaeology into wider archaeological landscapes, two cases are reviewed. One is an early study of land, $p \bar{a}$ and polity at Pouto in the northern Kaipara (Irwin 1985), and the other a preliminary report of a subsequent study in the islands of the Inner Hauraki Gulf (Irwin, Ladefoged and Wallace 1996). Pouto and Ponui are compared, and some other studies considered.

- The ethnography of social organisation and settlement pattern is reviewed and issues considered include community composition, territory and chieftainship.

- Finally, a discussion and some concluding remarks include a suggestion of continuity from late prehistory to early history.

\section{WHAT CAN WE SAY ABOUT $P \bar{A}$ ?}

A great deal is known about individual $p \bar{a}$ and the data have improved with the recent publication of substantial excavations like Pouerua (Sutton, Furey and Marshall 2003), Kohika (Irwin 2004) and Maungarei/Mt Wellington (Davidson 2011), but it remains difficult to generalise about them. Most of the archaeological features found in undefended sites also occur in $p \bar{a}$; however, many propositions such as whether houses and defences were normally contemporary with each other, or not, remain impressionistic while the existing corpus of excavated information remains unquantified, and quantification will present problems because the data are uneven.

- $\quad P \bar{a}$ appeared in the archaeological record around AD 1500 (Schmidt 1996). They were often associated with agricultural landscapes that have access to marine resources, and were sometimes very dense. Excavations have shown that many have long and complicated sequences, often beginning as undefended sites. Like many other sites, they are accumulations of short-term events over time (Holdaway 2004).

- $\quad P \bar{a}$ were very diverse in size and form, but analysis of form has scarcely advanced in decades. Suitable modern methods such as laser scanning and digital image analysis are now available. $P \bar{a}$ also had diverse functions. They defended people from attack, but the extent to which settlement was permanent or temporary is unresolved. $P \bar{a}$ were also monuments of the mana of communities, but the relative importance of defence or social identity is debated. $P \bar{a}$ also defended food stores in a seasonal economy and protected access to resources.

- The origins of $p \bar{a}$ might be better explained if they were better dated. Nearly 30 years ago I commented that while $p \bar{a}$ appeared to have been widespread from around AD 1500 it was not known when they were first built, or when a majority of them was built. It was not known where 
the early ones were built or how the idea of or the need for $p \bar{a}$ may have spread (Irwin 1985: 1). The current situation is not much improved. In this regard it is interesting to note that recent research on the chronology of earthwork sites of the British Neolithic using Bayesian statistical analysis has identified a point of origin for early causewayed camps and a chronological pattern to their spatial spread (Whittle, Healy and Bayliss 2011). Much the same could be possible here.

The significance of defence

By definition, what all $p \bar{a}$ have in common is defences. Much uncertainty and debate revolves around the evidence contained within them; however, defences themselves provide important information that is often overlooked:

- Firstly, all $p \bar{a}$ defences are based on simple devices, such as fences, ditches and banks, to impede an attacker, and they usually provide a height advantage for hand-to-hand combat.

- With very few exceptions, $p \bar{a}$ were completely enclosed by their defences, whether artificial or natural. This means the defences were more than just symbolic. As Davidson (1984: 185) remarked: "The significance of $p \bar{a}$ as focal points of community activity and centres of community pride and prestige is an important point, but one which should not be overemphasised at the expense of their defensive function."

- At the moment in time when a site was fortified a social group revealed itself in the archaeological record and we see an event at a communal level. Within the community there may have been a perception of external threat and, at that moment, the community and a wider social landscape were engaged.

- At such moments all $p \bar{a}$, however diverse, are comparable and certain points arise. Most obviously, we can suggest that the scale of the defence is a reflection of the size of the community or, in some cases, a proxy for the scale of the polity. And we can ask: What was the source of the threat - was it local or regional? When whole landscapes were fortified, social organisation and modes of integration such as leadership were operating at a landscape level as well as a communal one.

\section{Strategies for excavating and dating pā}

Excavating and dating $p \bar{a}$ can be a long and expensive process, but it is necessary to have a sufficient number of examples and models in order to address relevant questions. Tracing stratigraphic and chronological relationships through the structures and features of sites is complex but, again, defences come to our aid. Experience shows that, at any one time, the defences 
of a $p \bar{a}$ were usually complete. Therefore, we can extrapolate age horizontally through the defences further than through any other feature. Multiple defences such as separate ditches and banks can be dated independently or, where they have been rebuilt and overlap, they can be excavated at points of intersection, which are sometimes detectable from surface evidence. Dating defences is not always easy but it is a useful strategy and tells us one of the things we most want to know, which is when a site was functioning as a fortification. It is unfortunate and rather surprising that relatively few $\mathrm{C}^{14}$ dates from $p \bar{a}$ come from defences.

For some research questions dating only the defences can be useful, with the proviso that this does not inform us about what is being defended. However, it can indicate the size or scale of the community and it can support comparisons with other fortifications in the same settlement system, or elsewhere. The satisfactory dating of defences requires stratigraphic excavation and not simply the collection of samples for dating from eroding sections of $p \bar{a}$.

\section{EXAMPLES OF SETTLEMENT AT THE COMMUNAL LEVEL}

\section{Wetland archaeology}

About 20 percent of Polynesian material objects were archaeologically durable and the remainder normally perishable (Kirch and Green 2001). Information from wet sites has been easily incorporated into conventional frameworks based on dryland archaeology and important gaps in our knowledge of architecture and material culture have been filled by waterlogged discoveries of things elusive on dry land. Known sites occur mainly in the North Island and two common types are habitation sites or artefact finds (Gumbley, Johns and Law 2005). The former include swamp $p \bar{a}$, which were fortified villages or hamlets found in wetlands, on swamps, lakes and rivers. The second group comprises sites where only artefacts have been found, but no habitation. Most artefacts were not intended to be retrieved but there are cases where valuable carvings, often parts of buildings or canoes, were hidden in times of stress with the intention of retrieval later (Day 2009, Edson 1983). Minor sites include caches of horticultural tools casually buried near gardens and sometimes wooden or fibre tools that were kept in water to enhance their functions (Phillips, Johns and Allen 2002, Wallace 1983). In Europe it is often suggested that wetlands were marginal places (Van der Noort and O'Sullivan 2006), but they were mainstream in New Zealand where none of the artefacts found in water represent votive offerings in the same way. 
Kohika: A late prehistoric lake village

Kohika provides a rich picture of a Maori community in late prehistory (Irwin 2004) and contrasting survivals in the wet and the dry parts of the site suggest what kinds of evidence are missing routinely from dryland sites (Taylor and Irwin 2007). The village was located in the Rangitaiki Swamp in a lake in the fork of the Rangitaiki and Tarawera rivers, which joined to form an estuary, Te Awa o Te Atua near the sea. This was a volatile environment with common floods, frequent earthquakes and occasional volcanic eruptions. The people at Kohika chose to live with the risks, while rewards arose from the strategic location among waterways and the ease of canoe transport. It was occupied for two or three generations, abandoned after a flood, fortuitously preserved in peat and rediscovered in 1974.

Figure 1 is a contour map showing excavation areas and their designations, A to HS. The core of the island is sand from a former shoreline left stranded behind the coast which prograded in spurts following eruptions. Figure 2 is a portrait of life in the $p \bar{a}$ in $\mathrm{AD} 1700$ based on a reconstruction of the evidence, and many of the structures shown were contemporary because they were interrupted by the same flood. In the left of the painting is a chiefly household in Area HS featuring a carved house, whare whakairo. Stylistic analysis by Roger Neich showed that all of the carvings were by one artist, although the work of three other carvers was found elsewhere. Near the house was a pataka storehouse on poles and rough shelters for cooking. Alongside was a jetty and parts of canoes and cordage were recovered from the former lake. Large blocks of Mayor Island obsidian, which had been transported to the site by canoe, were broken up for tools. Obsidian was so abundant it was probably traded up-river into the central North Island.

The house illustrated in Area D in the sheltered bay at the north of the site (Fig. 2) was of simple pole and thatch construction showing clear status differentiation among households. The house was damaged by an earthquake, rebuilt immediately but, later on, surrounded by debris from a flood. There was an entrance in the palisade, another jetty and a laid path down into the water where fishing gear was stored at the lake edge. One striking find was a carved human figure which stood in the palisade facing out into the bay, to confront anyone who approached. These households, which were basic building blocks of the community, are more visible in wet sites than in dryland ones because they were raised above the water table by floors of sand. All houses were decorated to some extent, whatever the status of the occupants.

Another elite household has been found in Area E (Fig. 1), on the western side of the bay. A canoe landing made of massed rata (Metrosideros sp.) vine coils and an entrance in the palisade, led to an open court or marae 


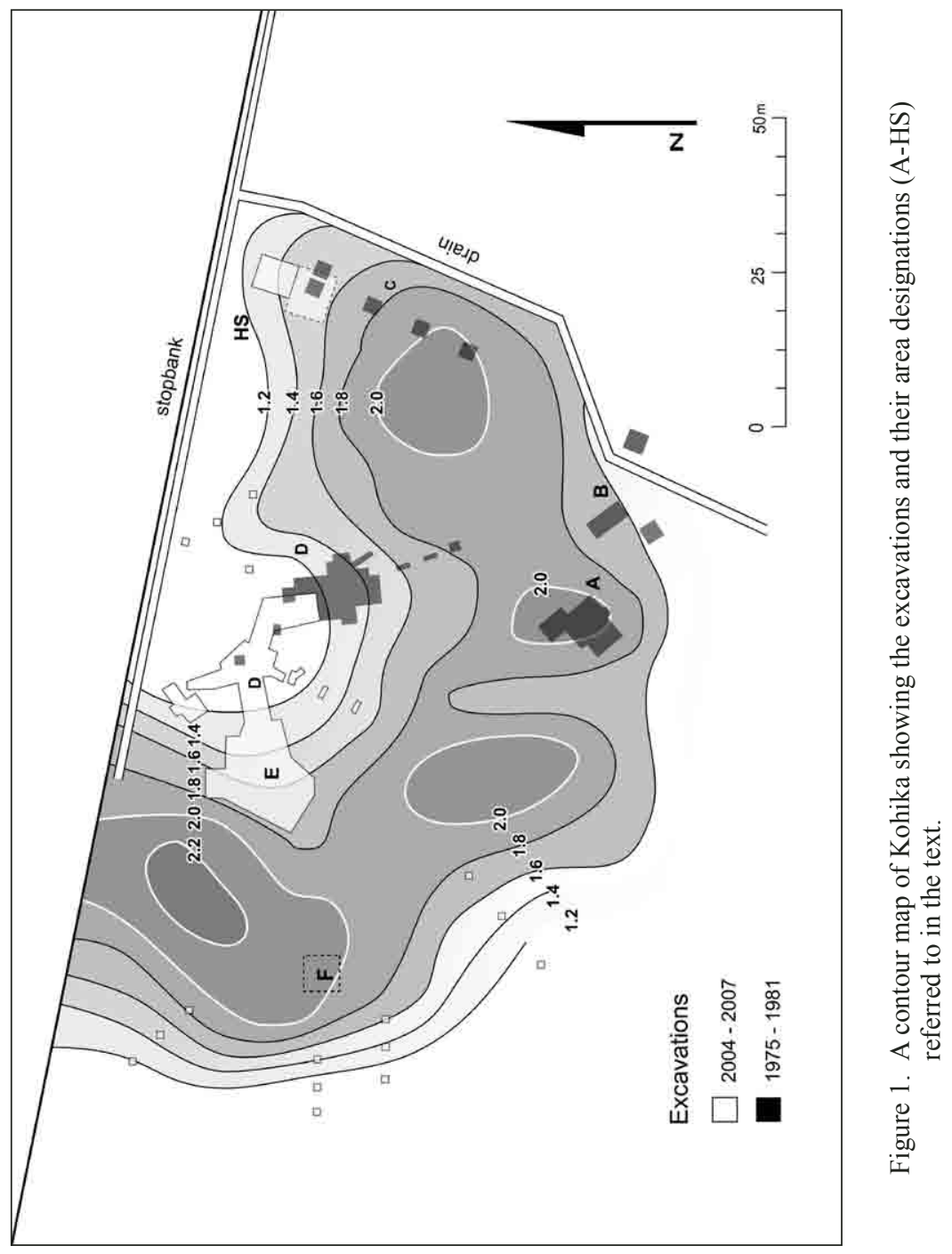




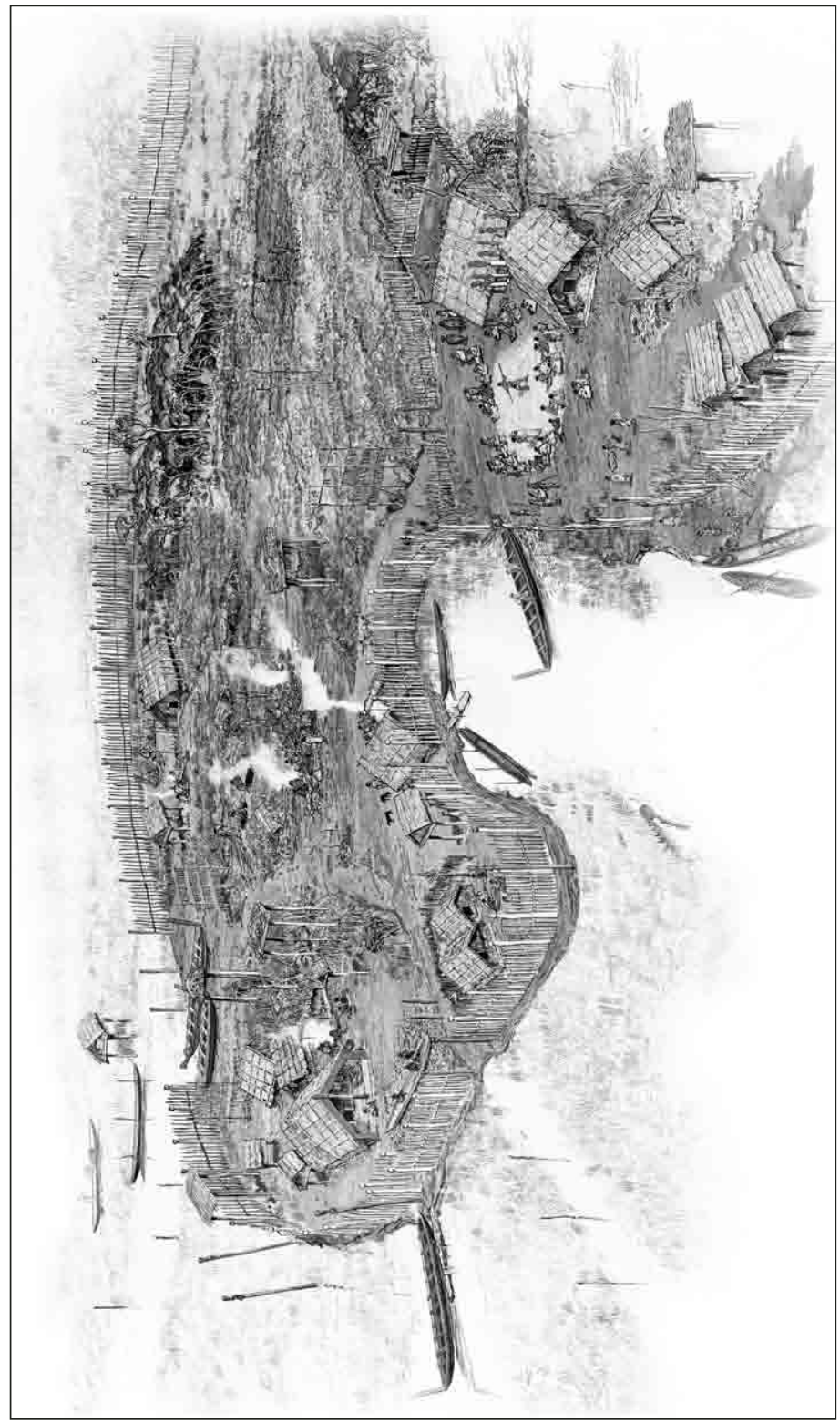

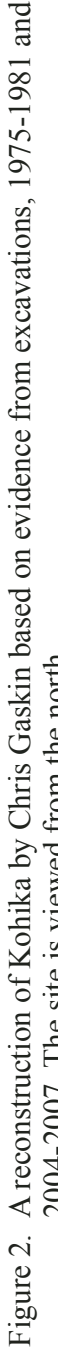


constructed of layers of sand, which were renewed from time to time for social and ceremonial occasions. Two superior houses made of dressed planks with traces of red ochre painting, and separated by a line of standing carved posts, stood adjacent to the marae. While many open spaces in settlements have been designated as marae by archaeologists, this is the most formal structure that I know of. A large number of diverse artefacts and thousands of flakes were found in the houses, but the court was scrupulously clean.

The general picture that emerges at Kohika is of a lightly defended village with an economy based on fishing, fowling, gathering shellfish, gardening, seafaring and trading. The community practiced a wide variety of industrial, craft, social and cultural activities, and had time for leisure, music, art and play. There was evidence for external connections to people from other areas.

Occupation ended not long after a flood, but Kohika had experienced floods before and this one did not inundate the island. One possibility is that the site became tapu, perhaps after an untimely death. The whare whakairo was left standing and the carvings were not hidden or buried, to be retrieved later. Abandonment could have been a result of political stress or warfare. When people left they took their weapons, but artefacts of every other kind, including several blades of pounamu, were left behind.

\section{Lake Mangakaware}

The question arises whether Kohika can be regarded as typical. In the Waikato there are several smaller swamp $p \bar{a}$, with fewer external connections, on small lakes rich in resources (Cassels 1972). Two settlements at the swampy margins of Lake Mangakaware, MA-1 and MA-2, were excavated during 1968-1970 (Bellwood 1978). They were found to be semi-artificial islands with lenses of sand laid on felled timbers at the lake edge. MA-1 was strongly fortified with palisades set into the lake and six lines of posts on the more vulnerable landward side. Divers groping in the soft lake bed recovered many wooden artefacts and building timbers. MA-2 was low-lying and about 2100 square metres in area and approximately 40 per cent of the occupied area was excavated. Some crucially important evidence was recovered. For the first time unambiguous house floors were recognised consisting of laid, rectangular sand floors delineated by wooden posts and vertical planks set in shallow bedding trenches. Previous excavations of dry-land sites had yielded many postholes, but few convincing house plans, and bedding trenches had been interpreted as drains. One house had a double wall of slender tree fern posts which could have been insulated for winter occupation. Two $\mathrm{C}^{14}$ samples from these posts indicated a 17 th century date. Contemporary houses were arranged around an open court or marae. The site was interpreted as being occupied year round but by a fluctuating population. 
Arguing from the case of Pouerua that evidence for sustained settlement in $p \bar{a}$ is generally lacking in excavated sites, Sutton et al. (2003: 231) suggested that the relationship of the houses with the defences at Mangakaware was "ambiguous"; however, as one who excavated there, I am satisfied that they were contemporary.

Kohika and Mangakaware allow us to consider some other current opinions. A review of the ethnographic and archaeological evidence of settlement patterns suggested to Phillips and Campbell (2004: 103) that, “... although houses are not uncommonly found, pa were not in general occupied except as necessary in periods of conflict. They should not be thought of as settlements in any standard sense...." This view may be too sweeping.

Bellwood (1978) speculates that at Mangakaware there was possible evidence of an attack. In the narrow entrance, between a double line of palisades through which people had to pass, there were five fragments from at least three stone hand clubs, two wooden spear points and two adze heads, and eight pieces of a human femur that had been smashed, burnt, covered with red ochre and left in a small earth oven. A small breast pendant was found just outside the palisade. Taken together these all may be interpreted as indicative of a case of hand-to-hand fighting.

\section{Oruarangi: A major riverside village}

Kohika gives us an insight into this famous site which can be taken as an example of a site of regional significance (see below). Built near the mouth of the Waihou River on natural levees where the river divided around an island, it has a remarkable collection of more than 3000 artefacts of stone and bone, possibly the richest and most diverse in New Zealand (Furey 1996), and used by Golson (1959) to define the material culture of the Classic phase of Māori culture.

Oruarangi was occupied when James Cook travelled up the river in 1769 in one of the Endeavour's boats with the scientists Joseph Banks and Daniel Solander, and the Tahitian navigator/priest, Tupaia, who could communicate with Māori (Beaglehole 1968: 207). Sidney Parkinson, artist on the Endeavour, described it thus: "Near the entrance of this river... there was a village, and a Hippa $[p \bar{a}]$, or place of refuge, erected to defend it, which was surrounded by piquets [palisades] that reached above the water when the tide was up, and, at low water, it was unapproachable on account of a deep soft mud" (Parkinson 1784: 106). The ship Fancy spent three months in the river from December 1794, cutting trees for spars and on one occasion her captain, Dell, reported 117 canoes around the ship at anchor and up to 2000 people on shore (Furey 1996: 14-15). In 1801, Oruarangi was the residence of the principal chief of the area and the $p \bar{a}$ was the gathering place for a large 
assembly of people going to war with Waikato tribes to the south. Oruarangi controlled the river and access to the hinterland and the wealth of artefacts reflects its importance (Phillips 2000).

In the early 1930s much of the site was ransacked by artefact-hunters; since then a number of investigations have attempted to recover what is left of the stratigraphy. Archaeology shows that the site was enlarged from time to time from the 16th century by the addition of fill quarried from natural shell banks near the river-mouth. By AD 1800 it had grown to 20,000 square metres and was heavily defended by a double row of palisades. Inside were concentrations of artefacts, possibly house floors, and other areas had debris from artefact manufacture (Best 1980, Furey 1996). Wooden house elements were recovered from nearby Paterangi (Bellwood 1978). Early amateur diggers spoke of canoe landings by the shore. Unfortunately, little is known of the waterlogged layers and for archaeology Oruarangi is a lost opportunity, so far.

\section{Kohika and Wairau Bar compared}

In a review of archaeological studies of social organisation Marshall states “... by the 1950s it was apparent that Archaic and Classic Maori had descended from a common ancestor... implying, if not requiring, significant cultural continuity and fundamental similarities in the social systems of the two cultures" (Marshall 2004: 56). In this context it is of interest to make a thumbnail comparison of Kohika with Wairau Bar which represent landmark sites at either end of the cultural sequence. Obviously, Wairau Bar is southern and Polynesian, and Kohika is northern and Māori, but there are some interesting parallels. Both were substantial and permanently occupied, containing the remains of housing and cooking areas. Both had a local economic resource base. Both were located at a river-mouth giving access to an extensive hinterland and also to long-distance connections by sea. Both have evidence for individuals of status, and for status differentiation-Wairau Bar in its burials and Kohika in its houses. Both had finely made artefacts and specialist craftsmen. Both have evidence for internal diversity-Wairau Bar in the genetic variation of individuals (Knapp et al. 2012) and Kohika in the differences between households in the extent of obsidian trade (Irwin 2004).

So, what changed during New Zealand prehistory? After a comprehensive review Walter, Smith and Jacomb concluded (2006: 274):

Despite... marked changes in subsistence practices there is little evidence in the archaeological or ethnographic record for any substantial alterations in patterns of mobility, sedentism or socio-political organization over the full duration of the New Zealand sequence. 
This is an insightful and reasonable conclusion, especially for the South Island, but it could be a more open question - perhaps the null hypothesis - for the densely-settled landscapes of the North Island, dominated by $p \bar{a}$. Were there any changes in the scale of settlement and organisation after around AD 1500? To address this question we need to look beyond the individual site into the wider landscape and we can extend some possibilities from the wet to the dry.

\section{LANDSCAPE APPROACHES TO THE STUDY OF $P \bar{A}$ ARCHAEOLOGY}

Pouto: An early case study

Pouto, at the southern end of the North Kaipara Head, is one of many areas in the North Island which feature dense archaeological landscapes where there appear to be coherent spatial relationships between sites and also between sites and the environment (Irwin 1885). However, the problem with fieldwork at this scale is that to spread archaeological resources more widely is to spread the evidence more thinly.

At Pouto $20 p \bar{a}$ were mapped; most of them were of small or medium size and lay in the horticultural hinterland. However, three large ones were located at the borders of Pouto, including the massive site of Rangitane-over 600 metres long with seven sets of transverse defences - on a ridge above Okaro Creek, which cuts off Pouto at the south of North Kaipara Head. Two $p \bar{a}$ were excavated and test excavations were made to obtain dates for defence building at another ten. Radiocarbon dates on samples of marine shell are shown in Figure 3.

It seems that there were initially just a few $p \bar{a}$ in Pouto and that most were built late in the pre-European period and could have overlapped in time. The sample of dates was very meagre and the results must be regarded with caution; however, such a pattern of similarly late dates was unlikely to occur at random. Spatial analysis by different methods produced consistent results:

- Nearest-neighbour analysis indicated that $p \bar{a}$ were regularly dispersed, which was taken as support for the notion that a significant number were contemporary. It appeared that the wider landscape of Pouto was defended not just a few individual sites. The undefended sites were found to cluster around key resources and around $p \bar{a}$.

- The rank-size distribution showed two groups of $p \bar{a}$. Many were small, roughly equivalent and independent units in a system that was not particularly integrated socially. The context of fortification was local and domestic and we can envisage sporadic stress among neighbours and kin, who had much in common but most to disagree about. In contrast, 
the rank and size of the three large sites suggested times of increased social integration. They were located on the periphery, two on poor soils, and could have been for regional defence. Rangitane protected the neck of Pouto from landward attack and the others defended the shore.

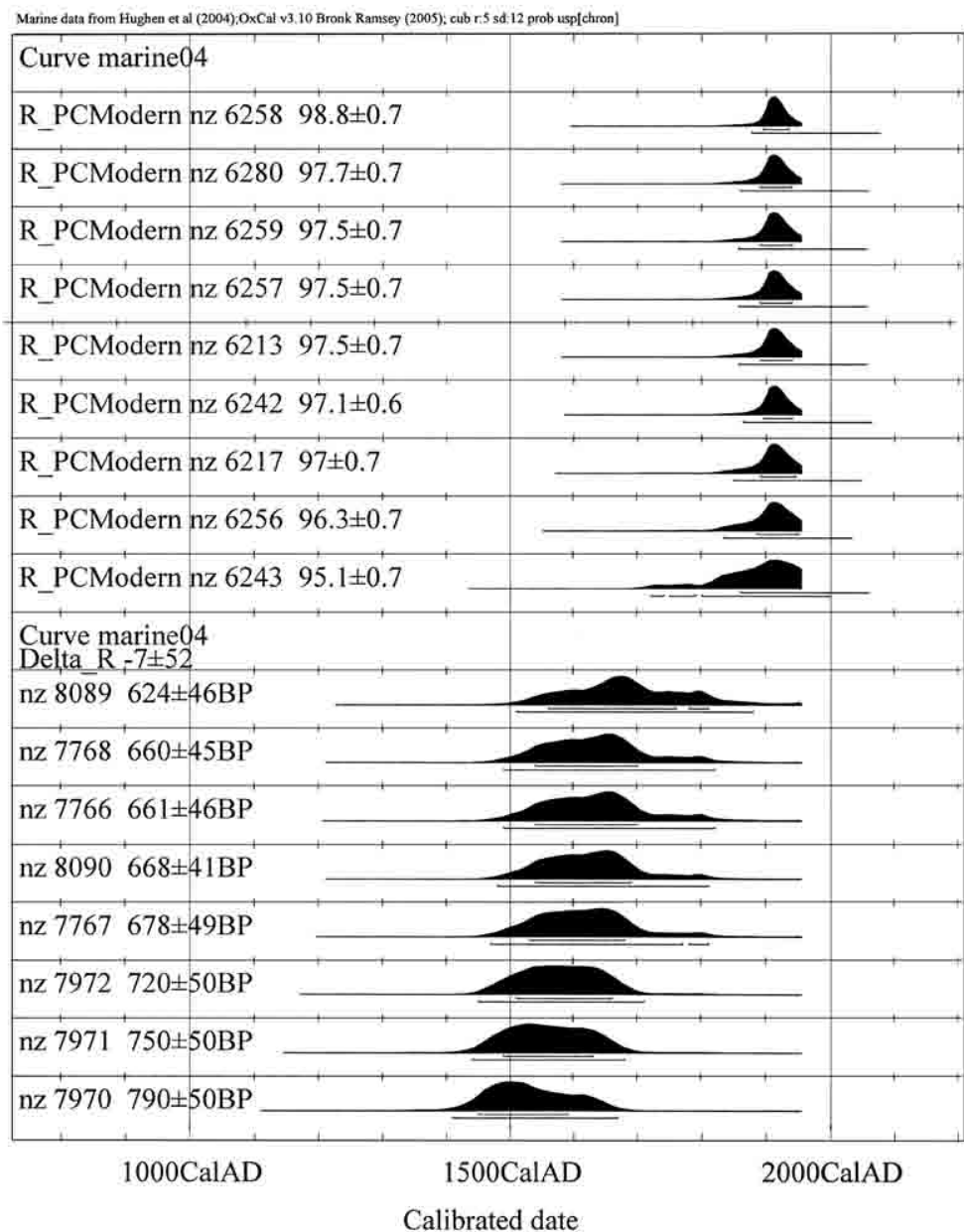

Figure 3. Radiocarbon dates on marine shell from the defences of $p \bar{a}$, the upper group from Pouto and the lower group from Ponui Island. Several $p \bar{a}$ were built in quick succession but at different times in the two places. 
- Network analysis supported the dual internal and external elements of social and political relations, with the smaller sites in the agricultural hinterland being more connected in local communications than those highest in rank-size, which were peripheral.

- A further analysis of the relative influence of sites supported the same two levels and also implied occasions when there could have been middle-order sites and individuals of influence, but only as the firstamong-equals. Overall, it seemed that the pattern of relations was dynamic and fluid.

The indications are that the landscape passed through some stress threshold and there was a rash of $p \bar{a}$ building in late prehistory. The settlement system experienced internal pressure, perhaps because the area of useful land was decreasing as gardens in a zone of fragile soils were lost to invading sand dunes. In addition, Pouto at times came under external stress or threat and there were episodes of integration for defence at a regional level. Interestingly, there are historical accounts of a long series of raids between hapu related to Ngāti Whatua in the North Kaipara and hapu of Nga Puhi south of the Hokianga Harbour. There was a battle in 1807, at Moremonui on the Kaipara coast, just north of Dargaville (Crosby 2012: 47); however, there were too few muskets present to influence the outcome. In 1820 a Ngā Puhi taua 'party of warriors' attacked Tauhara Pā at Pouto.

\section{The Inner Hauraki Gulf}

A subsequent study, still to be concluded, was set mainly on Ponui Island but involved Motutapu (Irwin et al. 1996). Fieldwork included a survey of Ponui (Fig. 4), excavation of an early coastal site (S11/20) and a nearby $p \bar{a}$ (S11/21), excavations at four open sites, test excavations at a range of coastal middens and also in the defences of $p \bar{a}$. Ponui, at the eastern end of Waiheke Island, had fewer than half the number of open sites as Motutapu at the other end, which can be attributed to the added fertility of the Rangitoto Ash on Motutapu, but there was a more similar number of $p \bar{a}$. An interesting feature of the Ponui $p \bar{a}$ was that many seem to have been residential, which was a point made by Kennedy (1969) for the Bay of Islands of 1772. Sedentary communities living in fortified villages are thought to be atypical of the North Island (Phillips and Campbell 2004); however, houses are still the most elusive features of New Zealand dry-land archaeology and it is hard to feel confident about their absence.

Undefended coastal sites pre-dated $p \bar{a}$ on Ponui (Sheppard et al. 2011) and continued through the sequence. A significant number of $p \bar{a}$ were first fortified during the 16th and early 17 th centuries and a reduced number 


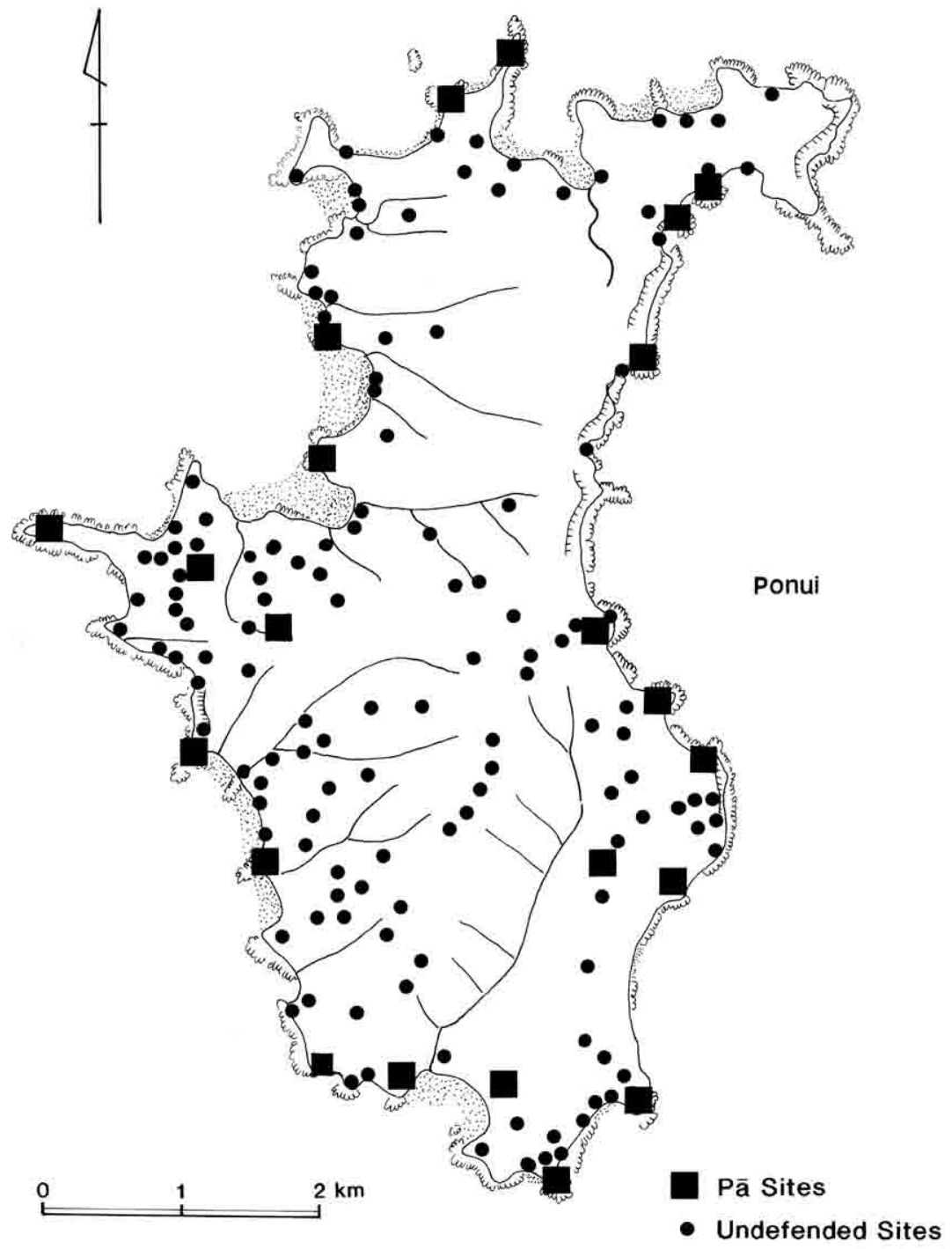

Figure 4. The distribution of archaeological sites on Ponui Island. 
later in prehistory. Undefended inland sites overlapped in time with $p \bar{a}$. The radiocarbon dates on marine shell from defences of six Ponui $p \bar{a}$ are shown in Figure 3 and contrasted with those from Pouto.

\section{Pouto and Ponui compared}

- There were episodes when $p \bar{a}$ were built in quick succession as a result of local pressures and issues.

- Events in different landscapes followed different trajectories and there was no single pattern of change.

- The construction of large $p \bar{a}$ in strategic locations could have been for regional defence, as different groups interacted. A wider scale of organisation and leadership was implied for such events.

- Settlement and society remained fluid and there was no clear evidence for permanent elites.

- Changes in tempo in late northern prehistory have been camouflaged by continuity in artefact style.

\section{Other theoretical approaches}

Archaeological approaches to the study of New Zealand settlement patterns have been reviewed by Marshall (2004) and Phillips and Campbell (2004), and there are ready-made theories available for interpretation. As one example, Mark Allen's (1996) study of polity formation in Hawkes Bay adopted Earle's (1991) view of Māori society as simple hill-fort chiefdoms. However, Allen's idea that discrete social units occupied fixed territories was at odds with other studies (Marshall 2004: 70), and very few $\mathrm{C}^{14}$ dates in his sample came from $p \bar{a}$ defences. Phillips (2000) used traditions in addition to archaeology in a narrative of 400 years of settlement on the Waihou River in the Hauraki district, and she followed Earle (1991) with reference to the emergence of larger political groups led by ariki. McCoy et al. (2014) tested the efficacy of Carniero's circumscription theory using obsidian artefact data from Pouerua Pā in the Inland Bay of Islands. These are examples of insightful studies which point the way ahead; however, at present, it is quality data that are in short supply in New Zealand archaeology rather than theory.

\section{SETTLEMENT PATTERN AND SOCIAL ORGANISATION}

\section{Community and territory}

From the time of Best (1927) comparisons have been made between field archaeology in New Zealand and Britain. Large numbers of Iron Age hill-forts were constructed in parts of Britain during the 5th and 6th centuries BC. All were characterised by a rampart, ditch and gate. It is generally thought they 
were constructed as a communal effort at the instigation of some authority and, like New Zealand $p \bar{a}$, they have been shown to be diverse, some with evidence of substantial occupation and storage, but others for little use. The British archaeologist Barry Cunliffe remarked: "Viewed spatially, it is difficult to resist the impression that these early hill-forts were sites to dominate discrete territories, often defined by natural features like river valleys." (Cunliffe 2013: 305). In New Zealand, with the benefit of ethnography and traditional history, such a parallel between community and territory falls apart. It is also where New Zealand may depart from other parts of East Polynesia.

In Māori society bilateral kinship allowed a flexible system of multiple rights to use resources and settle land. In both North and South Islands hapu commonly were not residential groups and settlements were occupied by members of more than one hapu. Individual rights to resources overlapped on the ground and mobility was high (Anderson 1998, Ballara 1998, Phillips 2000). H. Allen (1996: 670) concluded that: "The search for a reified hierarchy of social groups [such as whänau, hapū and iwi] that might have made an indelible imprint on the landscape and the archaeological record should be abandoned." At Pouto "... the essence of the archaeological evidence is that there were no discrete pre-European social building blocks to be found. Instead, they varied in a more continuous fashion in both size and scale. Social relations were very fluid. Centres of activity and influence ebbed and flowed" (Irwin 1985: 109). Whether this kind of situation applied earlier in prehistory is a matter of conjecture. It could be the case that earlier, more formal patterns of kinship and residence became fragmented through time by bilateral kinship and group mobility.

Social changes suggested for late prehistory were a shift from hapu to the multi-hapū community as an operational unit (Anderson 2009, Ballara 1998). Also, the Ngāi Tahu migrations have been described as "... part of a more general surge of mobility in Maori Society" (Tau and Anderson 2008). In the north, Sissons (1988) suggested the possibility of a re-ordering of society in the 18th century. He based this mainly on a change in the structure of traditions, but with his eye on the emerging archaeological evidence from Pouerua (Marshall 1987). The archaeology of Pouto told a similar story (Irwin 1985).

One can envisage a mosaic of shifting social and political relationships influenced by contingent events sometimes leaving a more precise record in whakapapa than in the ground. However, from an archaeological perspective we can be fairly confident that, whatever their composition, communities were defended as social units, and the scale of defence may reflect the scale of the polity. Regional centres become implicit archaeologically in late prehistory but more real in early history. Oruarangi could be an example of such a site at the cusp between the two. 


\section{Chieftainship}

Kirch and Green (2001) argued from linguistic evidence that "Ancestral Polynesian Society" was stratified and had hereditary chiefs, and Marshall (2004: 71) pointed out that a kernel of social complexity was present in New Zealand from the beginning, ready to respond to challenges presented by the environment. By historical times “... multi-hapu communities acknowledged one or a small group of chiefs as community leaders" (Anderson 2009: 45). In parallel with trends elsewhere in East Polynesia the increasing complexity of Māori chieftainship has been entertained at times (e.g., M. Allen 1996, Sutton 1990). However, Anderson (2009: 46) commented that possible changes in social structure and organisation might have some currency in the northern North Island, but the proposition had not been tested archaeologically to any significant extent.

Hypothetically, the increasing density of settlement could have affected social relations and political leadership. For example, in terms of mathematical combinations, as the number of places in a social network increased, the number of pair-wise links between them would have increased at a greater (quadratic) rate. Thus, if the number of sites was three, then the number of links was three; with six sites there were 15 links; with 12 sites 66, and so on. Moreover, within social networks, individual nodes were not equal in terms of information flow, and locational advantage (and disadvantage) could have been involved in the differentiation of places and people (Brughmans 2013). The context of chiefly authority would have changed as settlement and competition intensified in the north.

\section{CONCLUDING REMARKS}

In this paper I have been concerned with the emergence of late Māori settlement patterns in northern New Zealand. I began with a discussion of problems of $p \bar{a}$ interpretation - noting the lack of modern analysis - and considered excavation strategies which focus on defences. I suggested that the scale of defence could be used as a proxy for the scale of a polity. Three wetland $p \bar{a}$ were used as examples of communal sites. Mangakaware could be regarded as a community equivalent in status to many sites in the hinterland of Pouto or on Ponui Island.

Not far off the coast from Kohika is Whale Island where Cook's Endeavour encountered the large double sailing canoe illustrated by Spöring in 1769 . The canoe was crowded with people and may not have been going far, and it displays the diversity, wealth and status so conspicuous at Kohika. It could have come from somewhere like Kohika, which was close by in space and 
time. Shortly afterwards, Oruarangi was seen by the same eyewitnesses. It shared many attributes of location, function and status with Kohika, but was larger and was acting as a regional political centre. These sites make connections between prehistory and history, and between the wet and the dry.

A brief comparison was made between Kohika and Wairau Bar as significant communities at either end of the cultural sequence and some general elements of continuity were noted. To investigate changes in settlement pattern at the landscape level — and possible differences between north and south-I described case studies from Pouto and Ponui, and noted some others. I draw a number of conclusions from the material presented.

- Population growth and increasing competition are implicit in the archaeological record in parts of the North Island (Davidson1984: 222). $P \bar{a}$ were widespread after AD 1500.

- There were episodes when $p \bar{a}$ were built in quick succession as a result of local pressures and issues, but events in different landscapes varied.

- Some large $p a \overline{\text { in }}$ particular locations could have been built for regional defence as different groups interacted. A wider scale of organisation and leadership is implied for such times, but settlement patterns remained fluid.

- There are ethnographic suggestions of a trend from hapu-based to community-based residence and territoriality (Anderson 2009: 44). We might consider that if $p \bar{a}$ were occupied by mixed hapu and not by corporate kin groups, then their construction was as much for the defence of persons as an expression of mana.

- Chiefs operated within the context of circumstances which varied in scale, and whether there was a change in the nature of chieftainship remains an open question.

- Settlement and society were diverging regionally in New Zealand.

There is an interesting possibility of continuity in regional defence from late prehistory to early history. In the initial campaigns of the musket wars, people in many regions that came under attack from around 1820, gathered in major regional $p \bar{a}$ for defence. This happened at Putiki o Kahu on Waiheke, Mokoia on the Tamaki River, Te Totara at Thames, Mt Maunganui in the western Bay of Plenty, Matakitaki in the Waikato, Mokoia Island at Rotorua, and in other places (Crosby 2012). Because of the mismatch in war technologies, these regional centres were defeated in every case. A working hypothesis is that this pattern of regional defence had continued from late prehistory and was not entirely an invention in the early historic period. 
Whatever the case, it failed, and the development of gunfighter $p \bar{a}$ soon followed (Best 1927). Our attention is drawn immediately to pre-European $p \bar{a}$ of massive dimensions and strategic location such as Rangitane at Pouto and Maunganui (S11/65), which is the largest and highest centrally-located fort among the islands of the Inner Hauraki Gulf. Historical records show that Oruarangi in the Hauraki was an important centre at contact and in the early years of the historic period. Interestingly, excavations at Pouerua in the Inland Bay of Islands indicate that it was not defended at the end of the sequence (Sutton et al. 2003). Traditions suggest that it was not the site of an important battle and there was no evidence for a paramount chief there (Sissons, Wi Hongi and Hohepa 1987). The centres of power at the end of prehistory in the Inland Bay of Islands may have lain elsewhere.

Further archaeological case studies in the North Island would be useful and traditional history and whakapapa could illuminate the archaeology, especially for the late period.

\section{ACKNOWLEDGEMENT}

This paper is an updated and expanded version of an Elsdon Best Memorial Lecture which I delivered at the Annual General Meeting of the Polynesian Society 24 July 2013.

\section{REFERENCES}

Allen, Harry, 1996. Horde and hapu. The reification of kinship and residence in prehistoric Aboriginal and Maori settlement organisation. In J. Davidson, G. Irwin, B. Leach, A. Pawley and D. Brown (eds), Oceanic Culture History: Essays in Honour of Roger Green. Dunedin: New Zealand Journal of Archaeology Special Publication, pp. 657-74.

Allen, Mark, 1996. Pathways to economic power in Maori chiefdoms: Ecology and warfare in prehistoric Hawke's Bay. Research in Economic Anthropology 17: 171-225.

Anderson, Atholl, 1998. The Welcome of Strangers: An Ethnohistory of Southern Maori A.D. 1650-1850. Dunedin: Otago University Press with Dunedin City Council.

2009. Origins, settlement and society of pre-European South Polynesia. In G. Byrnes (ed.), The New Oxford History of New Zealand. Melbourne: Oxford University Press, pp. 21-46.

Ballara, Angela, 1998. Iwi: The Dynamics of Maori Tribal Organisation from c.1769 to c.1945. Wellington: Victoria University Press.

Beaglehole, J.C. (ed.), 1968. The Journals of Captain James Cook on His Voyages of Discovery: Vol. 1. The Voyage of the Endeavour 1768-1771. Cambridge: Cambridge University Press for the Hakluyt Society. 
Bellwood, Peter, 1978. Archaeological Research at Lake Mangakaware, Waikato, 1968-1970. New Zealand Archaeological Association Monograph 9. Dunedin.

Best, Elsdon, 1927. The Pa Maori. Dominion Museum Bulletin 6. Wellington.

Best, Simon, 1980. Oruarangi Pa: Past and present investigations. New Zealand Journal of Archaeology 2: 65-91.

Brughmans, Tom, 2013. Thinking through networks: A review of formal network methods in archaeology. Journal of Archaeological Method and Theory 20: 623-62.

Cassels, Richard, 1972. Human ecology in the prehistoric Waikato. Journal of the Polynesian Society 81: 196-247.

Crosby, Ron, 2012. The Musket Wars. Auckland: Libro International.

Cunliffe, Barry, 2013. Britain Begins. Oxford: Oxford University Press.

Davidson, Janet, 1984. The Prehistory of New Zealand. Auckland: Longman Paul. 1987. The Paa Maaori revisited. Journal of the Polynesian Society 96: 7-26. 2011. Archaeological investigations at Maungarei: A large Maori settlement on a volcanic cone in Auckland, New Zealand. Tuhinga 22: 19-100.

Day, Kelvin, 2009. The Waitara Swamp search, Taranaki, New Zealand. New Zealand Journal of Archaeology 30: 113-33.

Earle, Timothy, 1991. The evolution of chiefdoms. In T. Earle (ed.), Chiefdoms, Power, Economy and Ideology. Cambridge: Cambridge University Press, pp.1-15.

Edson, Stephen, 1983. Miracles do happen! The recovery by instalments of the Puteke carving. New Zealand Archaeological Association Newsletter 26: 221-27.

Furey, Louise, 1996. Oruarangi: The Archaeology and Material Culture of a Hauraki $\mathrm{Pa}$. Bulletin of the Auckland Institute and Museum 17. Auckland.

Golson, Jack, 1959. Culture change in prehistoric New Zealand. In J. Freeman and W. Geddes (eds), Anthropology in the South Seas. New Plymouth: Thomas Avery, pp. 29-74.

Gumbley, Warren, Dilys Johns and Garry Law, 2005. Management of Wetland Archaeological Sites in New Zealand. Wellington: Department of Conservation.

Holdaway, Simon, 2004. Theory: Aspect and phase. In L. Furey and S. Holdaway (eds), Change Through Time: 50 Years of New Zealand Archaeology. New Zealand Archaeological Association Monograph 26, Auckland, pp. 9-28.

Irwin, Geoffrey, 1885. Land, Pā and Polity: A Study Based on the Maori Fortifications of Pouto. New Zealand Archaeological Association Monograph 15. Auckland.

2004. Kohika: The Archaeology of a Late Maori Lake Village, Bay of Plenty, New Zealand. Auckland: Auckland University Press.

Irwin, Geoffrey, Thegn Ladefoged and Rod Wallace, 1996. Fieldwork in the Inner Hauraki Gulf, 1988-96. Archaeology in New Zealand 39: 254-66.

Kennedy, Jean, 1969. Settlement in the South-East Bay of Islands, 1772: A Study in Text-Aided Field Archaeology. Studies in Prehistoric Anthropology 3. Dunedin: Anthropology Department, University of Otago.

Kirch, Patrick V. and Roger C. Green, 2001. Hawaiki, Ancestral Polynesia. An Essay in Historical Anthropology. Cambridge: Cambridge University Press.

Knapp, Michael, K. Ann Horsburgh, Stefan Prost, Jo-Ann Stanton, Hallie Buckley, Richard Walter and Elizabeth Matisoo-Smith, 2012. Complete mitochondrial 
DNA genome sequences from the first New Zealanders. Proceedings of the National Academy of Sciences 45: 18350-54.

Marshall, Yvonne, 1987. Antiquity, Form and Function of Terracing at Pouerua Pa. Unpublished MA thesis, University of Auckland.

2004. Social organisation. In L. Furey and S. Holdaway (eds), Change Through Time: 50 years of New Zealand Archaeology. New Zealand Archaeological Association Monograph 26. Auckland, pp. 55-84.

McCoy, Mark, Thegn Ladefoged, Maria Codlin and Douglas Sutton, 2014. Does Carniero's circumscription theory help us to understand Maori history? An analysis of the obsidian assemblage from Pouerua $\mathrm{Pa}$, New Zealand (Aotearoa). Journal of Archaeological Science 42: 467-75.

Parkinson, Sydney, 1784. A Journal of a Voyage to the South Seas in His Majesty's Ship, The Endeavour. London: Charles Dilly and James Phillips.

Phillips, Caroline, 2000. Waihou Journeys: The Archaeology of 400 years of Maori Settlement. Auckland: University of Auckland Press.

Phillips, Caroline and Matthew Campbell, 2004. From settlement patterns to interdisciplinary landscapes in New Zealand. In L. Furey and S. Holdaway (eds), Change Through Time: 50 Years of New Zealand Archaeology. Auckland: New Zealand Archaeological Association Monograph 26, pp. 55-84.

Phillips, Caroline, Dilys Johns and Harry Allen, 2002. Why did Maori bury artefacts in the wetlands of pre-contact New Zealand? Journal of Wetland Archaeology 2: 39-60.

Schmidt, Matthew, 1996. The commencement of $p a$ construction in New Zealand prehistory. Journal of the Polynesian Society 105: 441-60.

Sheppard, Peter, Geoffrey Irwin, Sam Lin and Cameron McCaffrey, 2011. Characterization of New Zealand obsidian using PXRF. Journal of Archaeological Science 38: 45-56.

Sissons, Jeffrey, 1988. Rethinking tribal origins. Journal of the Polynesian Society 97: 199-204.

Sissons, Jeffrey, W. Wi Hongi and Pat Hohepa, 1987. The Puriri Trees are Laughing: A Political History of Nga Puhi in the Inland Bay of Islands. Auckland: The Polynesian Society.

Sutton, Douglas, 1990. Organisation and ontology: The origins of the Northern Maori chiefdom, New Zealand. Man 25: 667-92.

Sutton, Douglas, Louise Furey and Yvonne Marshall, 2003. The Archaeology of Pouerua. Auckland: Auckland University Press.

Tau, Te Maire and Atholl Anderson (eds), 2008. Ngai Tahu a Migration History: The Carrington Text. Wellington: Bridget Williams.

Walter, Richard, Ian Smith and Chris Jacomb, 2006. Sedentism, subsistence and sociopolitical organization in prehistoric New Zealand. World Archaeology 38: 274-90.

Taylor, Graeme and Geoffrey Irwin, 2007. The dry and the wet: The variable effects of taphonomy on the dog remains from the Kohika lake village, Bay of Plenty, New Zealand. In G. Clark, S. O'Connor and F. Leach (eds), Islands of Inquiry: Colonisation, Seafaring and the Archaeology of Maritime Landscapes. Canberra: Australian National University, pp. 453-74. 
Van der Noort, Robert and Aiden O'Sullivan, 2006. Rethinking Wetland Archaeology. London: Duckworth.

Wallace, Rod, 1983. Studies in the Conservation of Waterlogged Wood in New Zealand. Unpublished MA thesis, University of Waikato.

Whittle, Alisdair, Frances Healy and Alex Bayliss, 2011. Gathering Time: Dating the Early Neolithic Enclosures of Southern Britain and Ireland. Oxford: Oxbow Books.

\begin{abstract}
This paper is concerned with prehistoric changes in the scale of settlement, social organisation and chieftainship in northern New Zealand. It suggests an excavation strategy for $p \bar{a}$, describes examples of sites at a communal level and carries insights from wetland archaeology into the study of wider social landscapes. Increasing stress within landscapes is implicit in episodes of $p \bar{a}$ building, which occurred at different times in different places. Large strategic $p \bar{a}$ were built for regional defence and there is a suggestion of continuity into early history. A wider scale of organisation and leadership is implied for such times.
\end{abstract}

Keywords: Māori, archaeology, settlement, society, chieftainship 